\title{
Georgenia ruanii sp. nov., a novel actinobacterium isolated from forest soil in Yunnan (China), and emended description of the genus Georgenia
}

Correspondence

Wen-Jun Li

wjli@ynu.edu.cn

\author{
Wen-Jun Li, ${ }^{1} \dagger$ Ping $\mathrm{Xu},{ }^{1} \dagger$ Peter Schumann, ${ }^{2}$ Yu-Qin Zhang, ${ }^{1,3}$ \\ Rüdiger Pukall, ${ }^{2}$ Li-Hua Xu, ${ }^{1}$ Erko Stackebrandt ${ }^{2}$ and Cheng-Lin Jiang ${ }^{1}$ \\ 'Laboratory for Conservation and Utilization of Bio-Resources, Yunnan Institute of Microbiology \\ and Yunnan University, Kunming, Yunnan, 650091, People's Republic of China \\ ${ }^{2} \mathrm{DSMZ}$ - Deutsche Sammlung von Mikroorganismen und Zellkulturen $\mathrm{GmbH}$, Inhoffenstrasse \\ 7b, D-38124 Braunschweig, Germany \\ ${ }^{3}$ Institute of Medicinal Biotechnology, Chinese Academy of Medical Sciences and Peking Union \\ Medical College, Beijing 100050, People's Republic of China
}

\begin{abstract}
A Gram-positive, motile, short-rod-shaped strain, designated YIM 004 ${ }^{\top}$, was isolated from a forest-soil sample collected from Lijiang, Yunnan Province, China, and was investigated using a polyphasic taxonomic approach. The isolate contained chemotaxonomic markers that corresponded to those of its phylogenetic neighbour, Georgenia muralis, i.e. it possessed peptidoglycan type $A 4 \alpha$ with lysine as the diagnostic cell-wall diamino acid, the predominant

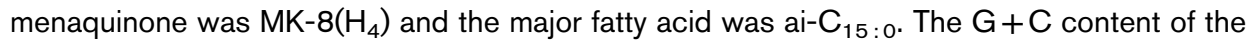
genomic DNA was 72.9 mol\%. Strain YIM $004^{\top}$ exhibited a $16 \mathrm{~S}$ rRNA gene sequence similarity of $97.3 \%$ and a DNA-DNA relatedness value of $18 \%$ with respect to G. muralis DSM $14418^{\top}$. On the basis of the phenotypic and genotypic differences between the isolate and G. muralis, strain YIM $004^{\top}$ represents a novel species of the genus Georgenia, for which the name Georgenia ruanii sp. nov. is proposed. The type strain is YIM 004 ${ }^{\top}\left(=\right.$ CCTCC AB $204065^{\top}=$ DSM $17458^{\top}=$ KCTC $\left.19029^{\top}\right)$. In addition, an emended description of the genus Georgenia is presented.
\end{abstract}

The genus Georgenia was proposed by Altenburger et al. (2002) with a single species, Georgenia muralis, the type strain of which was isolated from a medieval wall painting in the church of St Georgen in Styria, Austria. The cells were Gram-positive, oxidase- and catalase-positive, nonsporulating and non-motile and exhibited a rod-coccus cycle.

In the course of a screening programme for new antibiotics, some mesophilic bacteria that contained both type I and type II polyketide biosynthesis pathway genes were screened and identified by means of polyphasic taxonomy (Xu et al., 2003, 2005a, b). The present investigation was designed to clarify the taxonomic position of another novel strain containing these genes. Strain YIM $004^{\mathrm{T}}$ was isolated from a forest-soil sample collected from Lijiang, Yunnan Province, China, after 2 weeks incubation at $28^{\circ} \mathrm{C}$ on ISP 2 agar

TThese authors contributed equally to this work.

The GenBank/EMBL/DDBJ accession number for the 16S rRNA gene

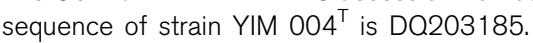

A transmission electron micrograph of cells of strain YIM $004^{\top}$ is available as a supplementary figure with the online version of this paper.
(Shirling \& Gottlieb, 1966). Comparative 16S rRNA gene sequence analysis revealed the isolate to be a member of the suborder Micrococcineae. On the basis of phenotypic and genotypic evidence, the novel isolate represents a novel species of the genus Georgenia.

All physiological and biochemical tests were performed at $28^{\circ} \mathrm{C}$. The colony morphology was determined after 3 days incubation at $28^{\circ} \mathrm{C}$ on ISP 2 and TSA [trypticase soy broth (BBL), 3\%, w/v; Bacto agar (Difco), $1.5 \%$, w/v] medium. Colour determination was achieved using colour chips from the ISCC-NBS colour charts (standard sample no. 2106) (Kelly, 1964). Gram staining was carried out using the standard Gram reaction and was examined by light microscopy (BH-2 microscope; Olympus). Cell motility was investigated on Luria-Bertani swarming agar $(0.3 \%$, w/v). Cellular morphology was studied by using a JEM-1010 electron microscope (JEOL) with cells from exponentially growing cultures. Oxidase activity was determined using a $1 \%$ solution of tetramethyl-p-phenylenediamine (Kovács, 1956). Catalase activity was determined by assessing the production of bubbles after the addition of a drop of $3 \%$ $\mathrm{H}_{2} \mathrm{O}_{2}$. The temperature range and optimum for growth were 
tested at $4-55^{\circ} \mathrm{C}$ on ISP 2 medium. The $\mathrm{pH}$ range and optimum for growth, tolerance of sodium chloride and phenol and susceptibility to antibiotics were examined as described by Xu et al. (2005a). Carbon utilization and acid production were tested using Micro-biochemical tubes (Hangzhou Tianhe Micro-organism Reagent). Some other physiological properties were tested by using the API ID 32E test kit (bioMérieux).

The cells of strain YIM $004^{\mathrm{T}}$ were short rod-shaped $(0.5-$ $0.8 \times 1.4-2.0 \mu \mathrm{m}$ ) and motile (amphitrichous, i.e. the cell has a single flagellum at each end, as shown in Supplementary Fig. S1 available in IJSEM Online). The cells were Gram-positive and chemo-organotrophic, with a respiratorytype metabolism. Endospores and poly- $\beta$-hydroxyalkanoate were not formed. The strain could not grow in the presence of sodium chloride at concentrations above $5 \%$. The temperature range for growth was $10-37^{\circ} \mathrm{C}$ and the $\mathrm{pH}$ range for growth was 6.5-10.0. Optimal growth occurred at $28-30^{\circ} \mathrm{C}$ and at $\mathrm{pH}$ 7.0. The results of the other physiological and biochemical analyses are summarized in the species description.

Analysis of sugars from whole-cell hydrolysates was performed using procedures described by Staneck \& Roberts (1974). Purified peptidoglycan preparations were obtained after disruption of the cells by shaking with glass beads and subsequent trypsin digestion according to the method of Schleifer (1985). The amino acids and peptides in the cell-wall hydrolysates were analysed by two-dimensional ascending TLC on cellulose plates using the solvent systems of Schleifer \& Kandler (1972). The N-terminal amino acid of the interpeptide bridge was determined by dinitrophenylation as described by Schleifer (1985). The molar ratios of the amino acids were determined by GC and GC-MS of the $\mathrm{N}$-heptafluorobutyryl amino acid isobutyl esters (MacKenzie, 1987). Analysis of the enantiomers of the peptidoglycan amino acids was performed by GC of the $\mathrm{N}$-pentafluoropropionyl amino acid isopropyl esters (Frank et al., 1980) on an L-Chirasil-Val column (Macherey-Nagel) as described by Groth et al. (1999).

Polar lipids were extracted from cultures grown in TSB, examined by two-dimensional TLC and identified using published procedures (Minnikin et al., 1979; Collins \& Jones, 1980). Menaquinones were isolated using the method of Collins et al. (1977) and were analysed by HPLC (Groth et al., 1997). Analysis of the whole-cell fatty acid pattern was performed using previously described methods involving the MIDI system (Microbial ID) (Kroppenstedt, 1985; Meier et al., 1993). The $\mathrm{G}+\mathrm{C}$ content of the DNA was determined by reversed-phase HPLC of nucleosides according to Mesbah et al.(1989).

The molar ratio of the amino acids in the peptidoglycan hydrolysate $\left(4 \mathrm{M} \mathrm{HCl}, 16 \mathrm{~h}\right.$ at $\left.100{ }^{\circ} \mathrm{C}\right)$ was approximately $3.1: 2.4: 1.0$ for alanine/glutamic acid/lysine. Glutamic acid and smaller amounts of alanine were detected as $\mathrm{N}$-terminal amino acids because of the incomplete cross-linkage of the interpeptide bridge. Enantiomeric analysis of the peptidoglycan amino acids revealed almost equimolar amounts of L- and D-glutamic acid and an L-alanine/D-alanine ratio of approximately $2: 1$. The peptides D-Ala $\leftarrow$ L-Lys $\leftarrow$ L-Ala and L-Lys $\leftarrow \mathrm{L}-\mathrm{Ala}$ were detected in the partial hydrolysate (4 M $\mathrm{HCl}, 45 \mathrm{~min}$ at $100^{\circ} \mathrm{C}$ ) of the peptidoglycan of strain YIM $004^{\mathrm{T}}$. From these data, it was concluded that strain YIM $004^{\mathrm{T}}$ possesses peptidoglycan of type A4 $\alpha$, with lysine as the diagnostic cell-wall diamino acid and an interpeptide bridge comprising $\mathrm{L}-\mathrm{Lys} \leftarrow \mathrm{L}-\mathrm{Ala} \leftarrow \mathrm{L}-\mathrm{Glu}$. The cell-wall sugars consisted of galactose and rhamnose. The polar lipids were phosphatidylinositol, phosphatidylglycerol, diphosphatidylglycerol and an unknown phospholipid. The menaquinone pattern was composed of $\mathrm{MK}-8\left(\mathrm{H}_{4}\right), \mathrm{MK}-7\left(\mathrm{H}_{4}\right)$, MK-9 $\left(\mathrm{H}_{4}\right)(90: 2: 1)$. The major fatty acids were ai- $\mathrm{C}_{15: 0}$ and $\mathrm{i}-\mathrm{C}_{15: 0}$; the detailed cellular fatty acid profile is reported in the species description. The $\mathrm{G}+\mathrm{C}$ content of genomic DNA from strain YIM $004^{\mathrm{T}}$ was $72.9 \mathrm{~mol} \%$.

Genomic DNA for PCR amplification was prepared from cells lysed by microwaves: a small amount of biomass was transferred from solid medium to a new Eppendorf tube. After the cells had been washed with $1 \mathrm{ml}$ PBS (pH 8.0) and $1 \mathrm{ml}$ washing buffer $[50 \mathrm{mM}$ Tris/ $\mathrm{HCl}, \mathrm{pH} 7.7 ; 25 \mathrm{mM}$ EDTA; $0.1 \%$ SDS; $0.1 \%$ polyvinylpyrrolidone (PVP)], $50 \mu \mathrm{l}$ lysis buffer (50 mM Tris/HCl, pH 8.0; 25 mM EDTA; $3 \%$ SDS; $1.2 \%$ PVP) was added to resuspend the cells, which were then heated at $700 \mathrm{~W}$ in a microwave oven for $45 \mathrm{~s}$. Next, $400 \mu \mathrm{l}$ warm extraction buffer $[10 \mathrm{mM}$ Tris/ $\mathrm{HCl}$, pH 8.0, $1 \mathrm{mM}$ EDTA, $0.5 \mathrm{M}$ sodium acetate, $1.2 \%$ PVP (pre-warmed at $65^{\circ} \mathrm{C}$ )] was added immediately and mixed with the cell suspension. An equal volume of phenol/chloroform was used for extraction. The DNA was precipitated with 2-propanol. The DNA was washed with $70 \%$ ethanol and dissolved using $20 \mu \mathrm{TE}$ solution.

PCR amplification and 16S rRNA gene sequencing were carried out as described previously (Cui et al., 2001). After a preliminary BLAST analysis (Altschul et al., 1997), the sequence of strain YIM $004^{\mathrm{T}}$ was aligned with those of related members of the class Actinobacteria,which had been retrieved from the GenBank database using the BLAST2 algorithm (Tatusova \& Madden, 1999). Sequence similarities were determined by using CLUSTAL X (Thompson et al., 1997). A phylogenetic tree was constructed, using the neighbour-joining method of Saitou \& Nei (1987), from $K_{\text {nuc }}$ values (Kimura, 1980, 1983) with MEGA, version 2.1 (Kumar et al., 2001). The topology of the phylogenetic tree was evaluated by using the bootstrap resampling method of Felsenstein (1985), with 1000 replicates.

The almost-complete 16S rRNA gene sequence (1516 nt) was determined for strain YIM $004^{\mathrm{T}}$. Phylogenetic analysis of strain YIM $004^{\mathrm{T}}$ revealed that the isolate was most closely related to G. muralis DSM $14418^{\mathrm{T}}$, the $16 \mathrm{~S}$ rRNA gene sequence similarity value being $97.3 \%$, and the two strains formed a distinct subclade within the suborder Micrococcineae (Fig. 1). 


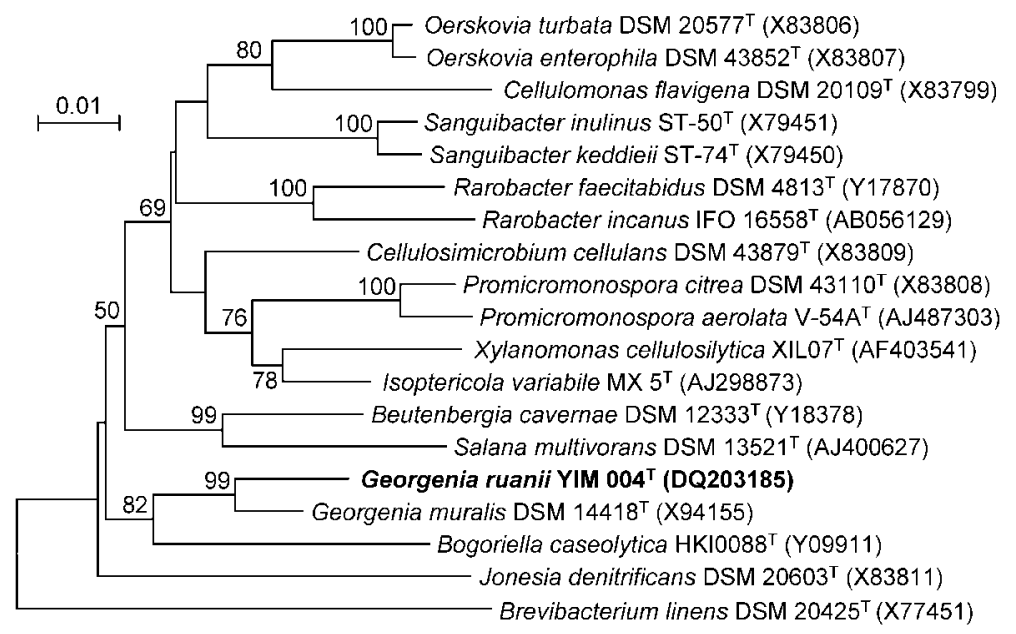

Fig. 1. Phylogenetic dendrogram, obtained by distance matrix analysis of $16 \mathrm{~S}$ rRNA gene sequences, showing the position of strain YIM $004^{\top}$ and its phylogenetic neighbours. Numbers at branch nodes are bootstrap values (from 1000 resamplings); only values of $50 \%$ or above are shown. The sequence of Brevibacterium linens DSM $20425^{\top}$ was used as the root. Bar, $1 \%$ sequence divergence.

To determine the genomic DNA relatedness (\%) between strain YIM $004^{\mathrm{T}}$ and G. muralis DSM $14418^{\mathrm{T}}$, DNA-DNA hybridization was carried out by applying the optical renaturation method (De Ley et al., 1970; Huß et al., 1983) and using a UV-Vis spectrophotometer (model UV1601; Shimadzu). Genomic DNAs from strains YIM $004^{\mathrm{T}}$ and G. muralis DSM $14418^{\mathrm{T}}$ were prepared according to the method of Marmur (1961); purified genomic DNAs were cut to generate DNA fragments between 400 and $800 \mathrm{bp}$ in size. Sheared genomic DNA (about $100 \mu \mathrm{g}$ ) from each sample was added to $2 \times$ SSC $(1 \times$ SSC is $0.15 \mathrm{M}$ sodium chloride plus $0.015 \mathrm{M}$ sodium citrate) and then denatured by raising the temperature to $100{ }^{\circ} \mathrm{C}$ and cooled to the melting temperature in the spectrophotometer. The samples were kept at the melting temperature for $3 \mathrm{~min}$ and the absorbance at $260 \mathrm{~nm}$ was recorded at $30 \mathrm{~s}$ intervals for a total of $30 \mathrm{~min}$. The initial reassociation kinetics were determined by using linear regression analysis. The percentage DNA homology for these two micro-organisms was calculated using the equation described by De Ley et al. (1970). All statistical analyses were performed using the EXCEL software (Microsoft). The DNA-DNA relatedness value obtained was $18 \%$ (mean from two experiments), significantly lower than the $70 \%$ value considered to be the threshold for the delineation of genomic species (Wayne et al., 1987).

The results of the 16S rRNA gene sequence analysis clearly demonstrated that strain YIM $004^{\mathrm{T}}$ is closely related to $G$. muralis DSM $14418^{\mathrm{T}}$. Both organisms contain MK- $8\left(\mathrm{H}_{4}\right)$ as the predominant menaquinone and have the same peptidoglycan type (A4 $\alpha)$ with lysine as the diagnostic cell-wall diamino acid. These properties support the inclusion of strain YIM $004^{\mathrm{T}}$ within the genus Georgenia. However, strain YIM $004^{\mathrm{T}}$ contains an interpeptide bridge composed of L-Lys $\leftarrow \mathrm{L}-\mathrm{Ala} \leftarrow \mathrm{L}-\mathrm{Glu}$, while the peptidoglycan of $\mathrm{G}$. muralis has peptide subunits that are cross-linked via a single L-glutamic acid residue. In addition, strain YIM $004^{\mathrm{T}}$ differs from G. muralis DSM $14418^{\mathrm{T}}$ by the presence of phosphatidylinositol, by possessing larger amounts of iso- $\mathrm{C}_{15: 0}$ and by some other phenotypic characteristics, as shown in Table 1.

The DNA-DNA relatedness data provide conclusive evidence that the novel isolate (YIM 004 ${ }^{\mathrm{T}}$ ) and G. muralis DSM $14418^{\mathrm{T}}$ are members of different genomic species (Wayne et al., 1987). Strain YIM $004^{\mathrm{T}}$ therefore represents a novel species of the genus Georgenia, for which the name Georgenia ruanii sp. nov. is proposed. As a consequence of newly reported characteristics not included in the original description of strain DSM $14418^{\mathrm{T}}$, the description of the genus Georgenia Altenburger et al. 2002 needs to be emended.

\section{Emended description of Georgenia Altenburger et al. 2002}

The description is based on that given by Altenburger et al. (2002). Cells are cocci or short rods that may exhibit a rod-coccus life cycle. Gram-positive, non-sporulating and motile or non-motile. Aerobic, but growth under anaerobic conditions can also occur. Oxidase- and catalase-positive. The peptidoglycan type is $\mathrm{A} 4 \alpha$ (based on lysine as diagnostic diamino acid). The major menaquinone is $\mathrm{MK}-8\left(\mathrm{H}_{4}\right)$. The polar lipids are diphosphatidylglycerol and phosphatidylglycerol; phosphatidylinositol mannoside or phosphatidylinositol can occur. There is a predominance of iso- and anteiso-branched fatty acids, with ai- $\mathrm{C}_{15: 0}$ as a major component. The $\mathrm{G}+\mathrm{C}$ content of the genomic DNA is 70-73 mol\%. Phylogenetically, the genus is a member of the suborder Micrococcineae, order Actinomycetales. The type species is Georgenia muralis.

\section{Description of Georgenia ruanii sp. nov.}

Georgenia ruanii [ru.a'ni.i. N.L. gen. n. ruanii of Ruan, named in honour of Ji-Sheng Ruan (born in 1926), a Chinese microbiologist who devotes himself to the study of actinomycete taxonomy].

Displays the following properties in addition to those described above for the genus. Colonies are 1.1-1.2 $\mathrm{mm}$ in diameter, circular, entire, slightly convex, opaque and pale 
Table 1. Characteristics used to differentiate between strain $\mathrm{YIM} 004^{\top}$ and its closest phylogenetic neighbour, G. muralis DSM $14418^{\top}$

The following characteristics apply to both strains: A4 $\alpha$-type peptidoglycan with lysine as the diagnostic cell-wall diamino acid; MK- $8\left(\mathrm{H}_{4}\right)$ as the predominant menaquinone; the assimilation of fructose, glucose, arabinose, galactose, sucrose, maltose, cellobiose, melibiose and salicin; the hydrolysis of starch and aesculin; the presence of lysine decarboxylase, $\beta$-glucosidase, $N$-acetylglucosaminidase and $\alpha$-glucosidase activities; and the absence of $\mathrm{H}_{2} \mathrm{~S}$ and indole production, urease, arginine dihydrolase, $\alpha$-galactosidase and $\beta$-glucuronidase. + , Positive; - , negative; $\mathrm{W}$, weakly positive.

\begin{tabular}{|c|c|c|}
\hline Characteristic & YIM $004^{\mathrm{T}}$ & G. muralis DSM $14418^{\mathrm{T}}$ \\
\hline Cell morphology & Short rods & Rod-coccus cycle \\
\hline Motility & + & - \\
\hline $\mathrm{pH}$ tolerance & $6.5-10.0$ & $6.0-9.0$ \\
\hline Maximum $\mathrm{NaCl}$ concentration for growth $(\%, \mathrm{w} / \mathrm{v})$ & 5 & 7 \\
\hline Maximum temperature for growth $\left({ }^{\circ} \mathrm{C}\right)$ & 37 & 45 \\
\hline Utilization of D-mannose & + & $\mathrm{W}$ \\
\hline Nitrate reduction & - & + \\
\hline$\beta$-Galactosidase & + & - \\
\hline$N$-Acetyl- $\beta$-glucosaminidase & + & - \\
\hline Cystine arylamidase & - & + \\
\hline Hydrolysis of Tween 80 & $\mathrm{~W}$ & - \\
\hline Polar lipids ${ }^{*}$ & DPG, PG, PI, 1 PL & $\begin{array}{l}\text { DPG, PG, PIM, } \\
2 \text { PLs, GL }\end{array}$ \\
\hline Peptidoglycan interpeptide bridge & L-Lys $\leftarrow$ L-Ala $\leftarrow$-Glu & L-Lys $\leftarrow$ L-Glu \\
\hline Major fatty acids $(>5 \%)$ & $\begin{array}{cc}\text { ai-C } & (78.3 \%) \\
\text { i-C } & \\
15: 0 & (14.9 \%)\end{array}$ & $\begin{array}{c}\text { ai- } C_{15: 0}(66.6 \%) \\
\quad i-C_{14: 0}(6.0 \%)\end{array}$ \\
\hline DNA $\mathrm{G}+\mathrm{C}$ content $(\mathrm{mol} \%)$ & 72.9 & 70.0 \\
\hline
\end{tabular}

${ }^{\star}$ DPG, Diphosphatidylglycerol; GL, unknown glycolipid; PG, phosphatidylglycerol; PI, phosphatidylinositol; PIM, phosphatidylinositol mannoside; PL, unknown phospholipid.

white-yellow to straw-coloured on ISP 2 agar. Cells are short-rod-shaped, $0.5-0.8 \times 1.4-2.0 \mu \mathrm{m}$ in size, and motile (by means of a single flagellum at each end of the cell). Chemo-organotrophic, with respiratory-type metabolism. Endospores and poly- $\beta$-hydroxyalkanoate are not formed. Does not grow in the presence of sodium chloride at concentrations above $5 \%$. Temperature range for growth is $10-37^{\circ} \mathrm{C}$, with optimum growth at $28-30^{\circ} \mathrm{C}$. $\mathrm{pH}$ range for growth is 6.5-10.0, with optimum growth at $\mathrm{pH} 7.0$. Tests for the hydrolysis of gelatin, for melanin production, $\mathrm{H}_{2} \mathrm{~S}$ production and indole production, for resistance to $\mathrm{KCN}$, for milk coagulation and for peptonization are negative. Nitrate is not reduced to nitrite. Dextrin, rhamnose, fructose, glucose, arabinose, sorbose, lactose, galactose, sucrose, dulcitol, inositol, maltose, mannose, cellobiose, turanose, mannitol, melibiose, melezitose, raffinose, ribose, salicin, xylitol, adonitol, arabitol, galacturonate and sorbitol are utilized as sole carbon and energy sources, and acid is produced from fructose, galactose, mannose, mannitol, xylose, ribose, lactose, glucose and sucrose. Starch and aesculin are hydrolysed and acetamide, xanthine, hypoxanthine and Tweens 20 and 80 are degraded weakly; urea is not degraded. Lipase, lysine decarboxylase, $\beta$-glucosidase,
$N$-acetyl- $\beta$-glucosaminidase, $\beta$-galactosidase, $\alpha$-maltosidase and L-aspartic arylamidase tests are positive, while arginine dihydrolase, ornithine decarboxylase, $\alpha$-galactosidase and $\beta$-glucuronidase tests are negative. Resistant to oleandomycin and nalidixic acid but sensitive to penicillin $G$, vancomycin, polymyxin B, erythromycin, terramycin, aureomycin, tetracycline, streptomycin sulfate, novobiocin, gentamicin and chloramphenicol. The peptidoglycan type is A $4 \alpha$ (L-Lys-L-Ala-L-Glu). The cell-wall sugars are galactose and rhamnose. The polar lipids are phosphatidylinositol, phosphatidylglycerol, diphosphatidylglycerol and an unknown phospholipid. The menaquinones are $\mathrm{MK}-8\left(\mathrm{H}_{4}\right)$, MK-7 $\left(\mathrm{H}_{4}\right)$ and MK-9 $\left(\mathrm{H}_{4}\right)(90: 2: 1)$. The cellular fatty acid profile consists mainly of ai- $\mathrm{C}_{15: 0}(78.3 \%)$ and $\mathrm{i}-\mathrm{C}_{15: 0}$ $(14.9 \%)$, with other minor components, including ai- $\mathrm{C}_{17: 0}$ (1.6\%), $\mathrm{C}_{14: 0}(1.0 \%)$, ai- $\mathrm{C}_{15: 1}(1.0 \%), \mathrm{C}_{16: 0}(1.0 \%)$, ai$\mathrm{C}_{13: 0}(0.7 \%), \mathrm{i}-\mathrm{C}_{16: 0}(0.6 \%), \mathrm{i}-\mathrm{C}_{17: 0}(0.5 \%), \mathrm{i}-\mathrm{C}_{14: 0}$ $(0.5 \%)$ and $\mathrm{i}-\mathrm{C}_{13: 0}(0.1 \%)$. The DNA $\mathrm{G}+\mathrm{C}$ content is $72.9 \mathrm{~mol} \%$.

The type strain, YIM $004^{\mathrm{T}}\left(=\right.$ CCTCC AB $204065^{\mathrm{T}}=\mathrm{DSM}$ $17458^{\mathrm{T}}=$ KCTC $19029^{\mathrm{T}}$ ), was isolated from soil in Lijiang, Yunnan Province, China. 


\section{Acknowledgements}

This research was supported by the National Basic Research Program of China (project no. 2004CB719601), the National Natural Science Foundation of China (project no. 30600001) and the Yunnan Provincial Natural Science Foundation (project no. 2004C0002Q). W.-J. L. was also supported by the Program for New Century Excellent Talent in University (NCET)

\section{References}

Altenburger, P., Kämpfer, P., Schumann, P., Vybiral, D., Lubitz, W. \& Busse, H.-J. (2002). Georgenia muralis gen. nov., sp. nov., a novel actinobacterium isolated from a medieval wall painting. Int J Syst Evol Microbiol 52, 875-881.

Altschul, S. F., Madden, T. L., Schäffer, A. A., Zhang, J., Zhang, Z., Miller, W. \& Lipman, D. J. (1997). Gapped BLAST and PSI-BLAST: a new generation of protein database search programs. Nucleic Acids Res 25, 3389-3402.

Collins, M. D. \& Jones, D. (1980). Lipids in the classification and identification of coryneform bacteria containing peptidoglycans based on 2,4-diaminobutyric acid. J Appl Bacteriol 48, 459-470.

Collins, M. D., Pirouz, T., Goodfellow, M. \& Minnikin, D. E. (1977). Distribution of menaquinones in actinomycetes and corynebacteria. $J$ Gen Microbiol 100, 221-230.

Cui, X. L., Mao, P. H., Zeng, M., Li, W. J., Zhang, L. P., Xu, L. H. \& Jiang, C. L. (2001). Streptomonospora salina gen. nov., sp. nov., a new member of the family Nocardiopsaceae. Int J Syst Evol Microbiol 51, 357-363.

De Ley, J., Cattoir, H. \& Reynaerts, A. (1970). The quantitative measurement of DNA hybridization from renaturation rates. Eur J Biochem 12, 133-142.

Felsenstein, J. (1985). Confidence limits on phylogenies: an approach using the bootstrap. Evolution 39, 783-789.

Frank, H., Rettenmeier, A., Weicker, H., Nicholson, G. J. \& Bayer, E. (1980). A new gas chromatographic method for determination of amino acid levels in human serum. Clin Chim Acta 105, 201-211.

Groth, I., Schumann, P., Rainey, F. A., Martin, K., Schuetze, B. \& Augsten, K. (1997). Demetria terragena gen. nov., sp. nov., a new genus of actinomycetes isolated from compost soil. Int J Syst Bacteriol 47, 1129-1133.

Groth, I., Schumann, P., Schuetze, B., Augsten, K., Kramer, I. \& Stackebrandt, E. (1999). Beutenbergia cavernae gen. nov., sp. nov., an L-lysine-containing actinomycete isolated from a cave. Int J Syst Bacteriol 49, 1733-1740.

Huß, V. A. R., Festl, H. \& Schleifer, K.-H. (1983). Studies on the spectrophotometric determination of DNA hybridization from renaturation rates. Syst Appl Microbiol 4, 184-192.

Kelly, K. L. (1964). Inter-Society Color Council - National Bureau of Standards Color-Name Charts Illustrated with Centroid Colors. Washington, DC: US Government Printing Office.

Kimura, M. (1980). A simple method for estimating evolutionary rates of base substitutions through comparative studies of nucleotide sequences. J Mol Evol 16, 111-120.

Kimura, M. (1983). The Neutral Theory of Molecular Evolution. Cambridge: Cambridge University Press.

Kovács, N. (1956). Identification of Pseudomonas pyocyanea by the oxidase reaction. Nature 178, 703-704.
Kroppenstedt, R. M. (1985). Fatty acid and menaquinone analysis of actinomycetes and related organisms. In Chemical Methods in Bacterial Systematics (SAB Technical Series), pp. 173-199. Edited by M. Goodfellow \& D. E. Minnikin. London: Academic Press.

Kumar, S., Tamura, K., Jakobsen, I.-B. \& Nei, M. (2001). MEGA2: molecular evolutionary genetics analysis software. Bioinformatics 17, 1244-1245.

MacKenzie, S. L. (1987). Gas chromatographic analysis of amino acids as the $N$-heptafluorobutyryl isobutyl esters. J Assoc Off Anal Chem 70, 151-160.

Marmur, J. (1961). A procedure for the isolation of deoxyribonucleic acid from microorganisms. J Mol Biol 3, 208-218.

Meier, A., Kirschner, P., Schröder, K.-H., Wolters, J., Kroppenstedt, R. M. \& Böttger, E. C. (1993). Mycobacterium intermedium sp. nov. Int J Syst Bacteriol 43, 204-209.

Mesbah, M., Premachandran, U. \& Whitman, W. B. (1989). Precise measurement of the $\mathrm{G}+\mathrm{C}$ content of deoxyribonucleic acid by highperformance liquid chromatography. Int J Syst Bacteriol 39, 159-167. Minnikin, D. E., Collins, M. D. \& Goodfellow, M. (1979). Fatty acid and polar lipid composition in the classification of Cellulomonas, Oerskovia and related taxa. J Appl Bacteriol 47, 87-95.

Saitou, N. \& Nei, M. (1987). The neighbor-joining method: a new method for reconstructing phylogenetic trees. Mol Biol Evol 4, 406425.

Schleifer, K. H. (1985). Analysis of the chemical composition and primary structure of murein. Methods Microbiol 18, 123-156.

Schleifer, K. H. \& Kandler, O. (1972). Peptidoglycan types of bacterial cell walls and their taxonomic implications. Bacteriol Rev 36, 407-477.

Shirling, E. B. \& Gottlieb, D. (1966). Methods for characterization of Streptomyces species. Int J Syst Bacteriol 16, 313-340.

Staneck, J. L. \& Roberts, G. D. (1974). Simplified approach to identification of aerobic actinomycetes by thin-layer chromatography. Appl Microbiol 28, 226-231.

Tatusova, T. A. \& Madden, T. L. (1999). BLAST 2 sequences - a new tool for comparing protein and nucleotide sequences. FEMS Microbiol Lett 174, 247-250.

Thompson, J. D., Gibson, T. J., Plewniak, F., Jeanmougin, F. \& Higgins, D. G. (1997). The CLUSTAL_X windows interface: flexible strategies for multiple sequence alignment aided by quality analysis tools. Nucleic Acids Res 25, 4876-4882.

Wayne, L. G., Brenner, D. J., Colwell, R. R., Grimont, P. A. D., Kandler, O., Krichevsky, M. I., Moore, L. H., Moore, W. E. C., Murray, R. G. E. \& other authors (1987). International Committee on Systematic Bacteriology. Report of the ad hoc committee on reconciliation of approaches to bacterial systematics. Int J Syst Bacteriol 37, 463-464.

Xu, P., Li, W. J., Zhang, Y. G., Tang, S. K., Gao, H. Y., Xu, L. H., He, B. K. \& Jiang, C. L. (2003). Molecular screening and distribution of polyketide antibiotics producers from Actinomycetes. J Chin Antibiot 28, 321-324.

Xu, P., Li, W. J., Tang, S. K., Zhang, Y. Q., Chen, G. Z., Chen, H. H., Xu, L. H. \& Jiang, C. L. (2005a). Naxibacter alkalitolerans gen. nov., sp. nov., a novel member of the family Oxalobacteraceae isolated from China. Int J Syst Evol Microbiol 55, 1149-1153.

Xu, P., Li, W. J., Tang, S. K., Jiang, Y., Chen, H. H., Xu, L. H. \& Jiang, C. L. (2005b). Nocardia polyresistens sp. nov. Int J Syst Evol Microbiol 55, 1465-1470. 